\title{
Art and Heterodoxy in the Dutch Enlightenment
}

\section{Arnold Houbraken, the Flemish Mennonites, and Religious Difference in The Great Theatre of Netherlandish Painters and Painteresses (1718-1721)}

\author{
Nina Schroeder | ORCID: 0000-0002-5861-836X \\ Vrije Universiteit Amsterdam, Amsterdam, The Netherlands \\ h.c.m.schroeder@vu.nl
}

\begin{abstract}
This paper considers the artist Arnold Houbraken (166o-1719) as an unconventional Christian and sheds new light on his representation of artists from religious minority groups in his Great Theatre of Netherlandish Painters and Painteresses (1718-1721). By exploring Houbraken's years within the Flemish Mennonite milieu in Dordrecht (166oca. 1685) and investigating his representation of religious difference in his biographies within The Great Theatre, this study extends scholarship on Houbraken beyond the current focus on his later years as a writer in Amsterdam, and it offers findings on the experience and reception history of nonconformists and religious minority group members, like the spiritualist David Joris and the Mennonite martyr Jan Woutersz van Cuyck (among others), within the Dutch art world. The paper also addresses the historiographical disconnect between literature in the disciplines of art history, intellectual history, and history of religion that persisted until very recently regarding Houbraken's status as a heterodox Enlightenment thinker.
\end{abstract}

\section{Keywords}

Arnold Houbraken - De groote schouburgh der Nederlantsche konstschilders en schilderessen - artist biographies - Dutch Republic - Mennonites - heterodoxy Enlightenment 
The magnum opus of Dutch artist and art theorist Arnold Houbraken (166o1719) is his three-volume biography of Dutch artists, De groote schouburgh der Nederlantsche konstschilders en schilderessen [The Great Theatre of Netherlandish Painters and Painteresses-hereafter, The Great Theatre] (1718-1721). ${ }^{1}$ This set of publications remains a key resource for current research on Dutch painters, their oeuvres, and their networks. Until relatively recently, Houbraken and his writing have primarily been a focus of attention among art historians; however, Houbraken has increasingly become a person of interest in intellectual history research on Enlightenment thought in the Dutch Republic.

The Great Theatre includes excerpts from Houbraken's own anonymously published, theologically heterodox treatises of ${ }^{1712-1713}{ }^{2}$ Furthermore, Houbraken presents biographies of an array of artists who were religious dissenters, nonconformists, or minorities in their day. In doing so he preserves anecdotes regarding early modern artists' experiences of marginalization and tolerance. Furthermore, his commentary sheds light on some of his own perspectives regarding religion and art; both the historical details and how they are recounted also underscore broader changes to Dutch socio-religious mores over the decades.

Since Houbraken published all his written work-two emblem books, two treatises and his Great Theatre - between 1700 and his death in $1719,{ }^{3}$ scholarship in both disciplines of art history and intellectual history regarding Houbraken's theology and writing has so far focused primarily on the last years of his life, and the scandal that his treatises raised among the Dutch Reformed in the early eighteenth century, rather than the first decades of his life during which he was a Mennonite. However, these early Mennonite years should not be overlooked: they represent Houbraken's first experiences of religious difference. By focusing attention here, this paper also addresses the need for more

1 Arnold Houbraken, De groote schouburgh der Nederlantsche konstschilders en schilderessen (Amsterdam: By the Author, 1718-1721; 2nd ed., The Hague: J. Swart, C. Boucquet, and M. Gaillard, 1753). Pagination cited here is from the 1753 second edition. All translations by author unless noted otherwise.

2 Hendrik J. Horn, The Golden Age Revisited: Arnold Houbraken's Great Theatre of Netherlandish Painters and Painteresses, 2 vols. (Doornspijk, 2000), 50-54.

3 The first publication was an emblem book of models for artists, unlike his other theological and historical work. Arnold Houbraken, Toneel van sinnebeelden, geopent tot dienst van schilders, beelthouders etc., 3 vols. (Dordrecht: Niclaes de Vries, 170o). There are several versions of the publication with some variations in content. Horn, Golden Age Revisited (see above, n. 2), 1: 35 and 2: 719, n. 2-130 to 2-132. He also produced illustrations for more than 20 publications. For a summary and further bibliography, Horn, Golden Age Revisited (see above, n. 2), 1: 14-15, 6o, and 2: 709, n. 2-27 to 2-29. 
extensive assessment of Mennonite engagement with fine art from both sociocultural and theological vantage points. ${ }^{4}$

Houbraken's choice to include several religiously unconventional artists' biographical details, and his tendency to cite sources, unlike some other artist biographers of the era, ${ }^{5}$ makes The Great Theatre a useful resource for research on both Houbraken's own heterodoxy and the topic of religious difference in the Low Countries and the Dutch Republic. The Great Theatre offers yet another avenue for considering how religious otherness took form, or was shaped further, within factions of society beyond the ranks of most famous ministers, professional scholar-theologians, and religious reformers. Artists constitute an important group for consideration because of the spectrum in lifestyle and experience they represent, ranging from practical bread-earning craftspeople to those who fashioned themselves as scholarly artist-gentlemen and women.

The discussion that follows here will examine Houbraken's own status and biography as an unconventional Christian and make use of The Great Theatre to investigate artists who found themselves outside of the contours of the Dutch Reformed mainstream. Houbraken shows himself to be well versed in the writing of many dissident and heterodox early Enlightenment thinkers, and he himself can also be counted among their number: he weaves their voices as well as his own theoretical asides on art, theology, and history into his Great Theatre-a work that was intended for a wide (educated) Dutch audience and that continues to function as a foundational source in Dutch art history.

\section{Art History and Intellectual History on Houbraken as a Heterodox Writer}

\subsection{Houbraken's Written Oeuvre}

Following a trajectory from Mennonite minority group member to heterodox Calvinist, Houbraken's theological views fell outside of Reformed theological norms. Houbraken was a part of the Dordrecht Flemish Mennonite congregation into early adulthood-probably at least until his marriage in 1685 . He

4 This gap in the literature has been raised many times, most recently in Magdalena Redekop, Making Believe: Questions about Mennonites and Art (Winnipeg, 2020), xxvii, 263-264.

5 Other art biographers like Joachim Sandrart, Florent le Comte, and Roger de Piles generally did not acknowledge sources. Cornelis Hofstede de Groot, Arnold Houbraken und seine "Groote Schouburgh" kritisch beleuchtet (The Hague, 1893), 48; Peter Hecht, "Browsing in Houbraken: Developing a Fancy for an Underestimated Author," Simiolus 24 (1996), 259-274, there 261; Horn, Golden Age Revisited (see above, n. 2), 1: 116 and 2: 750, n. 3-15o to n. 3-151. 
immersed himself in ideas of writers who were considered theologically controversial, and he was also inspired by the Collegiants. Late in life, Houbraken drew the attention of his contemporaries - and provoked the ire of the orthodox Dutch Reformed - with his anonymously published Brieven van Philalethes [Letters of Philalethes] (1712) and the follow-up, De gemeene leidingen [General Guidelines], which he then had published again together in one volume in $1713 .{ }^{6}$ These works covered a host of topics including art, theology, and antiquity, and they argued for rationalism in faith, displaying his affinity for the views of many controversial writers of the Dutch Enlightenment who argued against superstition, angels, and devils. ${ }^{7}$

Though Houbraken's writing was not banned, Letters of Philalethes quickly came to the attention of the Dutch Reformed Church authorities. ${ }^{8}$ As Jonathan Israel points out, the church council of South Holland discussed the Letters of Philalethes at its synod in July $1712 . .^{9}$ It was also condemned at the Synod of Gelderland in August 1713, at which time the author's defence of Dutch minister and philosopher, Frederik van Leenhof (1647-1715), who was considered controversial at that time for his Spinozistic sympathies as expressed in Hemel op Aarde [Heaven on Earth] (1703), was highlighted as one of its most "offensive features." ${ }^{10}$ Houbraken himself was also called before the Amsterdam consistory in 1713 on account of his writing: it was only after several further discussions within this group, once Houbraken had departed for a short

6 Anonymous [Houbraken], Brieven van Philalethes of Verzameling van uitgelezene keurstoffen and De gemeene leidingen tot den godsdienst afgebroken, en wederopgebouwt op vasten grond in Verzameling van uitgelezen keurstoffen ... (Amsterdam: Johannes Oosterwyk and Hendrik vande Gaete, 1713; 2nd ed. [under his name, Arnold Houbraken,] The Hague: Hendrik Versteeg, 1729). Hereafter, Letters of Philalethes and General Guidelines.

7 Horn, Golden Age Revisited (see above, n. 2), 38-39. Also see Jonathan Israel, "Popularizing Radical Ideas in the Dutch Art World of the Early Eighteenth Century: Willem Goeree (1635-1711) and Arnold Houbraken (166o-1719)," in From Confessional Churches to Polite Piety in the Dutch Republic, ed. Joke Spaans and Jetze Touber (Leiden, 2019), 270-291, there 284. Houbraken is placed in the context of the thought of Spinoza, Koerbagh, Bekker, Gracian, Van Leenhof, Geulincx, Vossius, Van Dale, Wittichius, Wolsgryn, Bayle, Hobbes, and Van Balen.

8 The letters, addressed to pseudonyms, were likely actual letters edited for publication. Most are to "Eusebius," who is likely Jacob Zeeus (1686-1718). Horn, Golden Age Revisited (see above, n. 2), 47-48.

9 Though he refers to the work as by Goeree, Israel helpfully notes that the author "ridicules belief in angels and spirits, questions the divine authorship of Scripture, denies the Trinity, and following Beverland, reduces the Fall to an allegory of sexual desire." Jonathan Israel, Radical Enlightenment: Philosophy and the Making of Modernity 1650-1750 (Oxford, 2002), 432 and n. 186.

Ibid., 406-436, especially 432 and n. 190. 
sojourn in England, that the focus on the matter diminished. ${ }^{11}$ Houbraken's anonymous writing was considered controversial, and he was quickly recognized as the author. ${ }^{12}$ Around this time, Houbraken also produced a moralizing emblem book, the Stichtelyke Zinnebeelden [Edifying Emblems], which would ultimately be finalized in collaboration with Gezine Brit (ca. 1669-1747) near the end of his life and published posthumously.13

The Great Theatre, finished in the last years of Houbraken's life, is a threevolume series of artist biographies intended to carry on the tradition of great artist biographers like Pliny, Vasari, and especially his fellow Dutchman, Flemish refugee and Mennonite, Karel van Mander (1548-16o6), whose SchilderBoeck of 1604 included details on the lives of Italian artists and Dutch artists, as well as a translation of Ovid meant as a reference work for artists. After Houbraken's death, his widow and his son took care of publishing the third volume. Houbraken draws upon many near-contemporary art biographers and theorists including the likes of Joachim Sandrart (16o6-1688), Cornelis de Bie (1627-1715), Roger de Piles (1635-1709), and his last art teacher, Samuel van Hoogstraten (1627-1678). However, more than half of the artists that Houbraken writes about are new to The Great Theatre, based on his own research and knowledge. ${ }^{14}$ Houbraken picks up from where Karel van Mander left off, completing the biographies of artists who were still active when the SchilderBoeck was published, and adding some artists that he felt Van Mander unduly skipped. Houbraken then carries on with artists of the seventeenth century up to and including his contemporary times.

11 David de Witt discovered the archival records that outline the consistory meetings with Houbraken. See transcription in Horn, Golden Age Revisited (see above, n. 2), 1: 59-6o and 2: 729, n. 2-271.

12 His authorship is referred to in the poem Lyris (see discussion below); Houbraken confirms his authorship in The Great Theatre; his friend and fellow artist-biographer Johan van Gool (1685-1763) notes Houbraken's situation too and, as mentioned above, Houbraken later republished the treatises under his name. See Johan van Gool, De nieuwe schouburg der Nederlantsche kunstschilders en schilderessen ..., 2 vols. (The Hague: For the Author, 1750-1751), 1: 131-147, there especially 145; Horn, Golden Age Revisited (see above, n. 2), 1: 145 and 2: 729, n. 2-270.

13 Arnold Houbraken and Gezine Brit, Stichtelyke zinnebeelden; Gepast op deugden en ondeugden, in LVII tafereelen. En verrykt met de bygedichten van Juffr. Gezine Brit (Amsterdam: Willem Barents, 1723; reissued Amsterdam: Isaak Tirion, 1729; 2nd ed. Amsterdam, heirs of Frans Houttuyn, 1767). On Brit, see discussion below.

14 Dedalo Carasso, "Houbrakens Groote Schouburgh: Enkele beschouwingen over de invloed van de Groote Schouburgh op ons beeld van de Noordnederlandse schilderkunst in de Gouden Eeuw," Theoretische Geschiedenis 26 (1996), 330-343, there 333-334. See also, Horn, Golden Age Revisited (see above, n. 2), 1: 84. 


\subsection{Renewed Scholarly Attention to Houbraken as a Heterodox Thinker}

Study of Houbraken within Enlightenment intellectual history has begun to flourish in the last several years, delayed in part by a disconnect between research questions passed down within the disciplines of art history and intellectual history respectively. ${ }^{15}$ Houbraken's status as a dissident thinker and author of anonymous theoretical treatises has been well known in modern art historical literature since the foundational study on Houbraken by Cornelis Hofstede de Groot in 1893; however, De Groot deemed the content largely inconsequential for art historical research, and this dismissiveness toward Houbraken's theological asides within The Great Theatre persisted among most subsequent art historians. ${ }^{16}$ Houbraken's heterodox views were taken up again by art historian Michiel Roscam Abbing in 1994 and most thoroughly explored in Hendrik Horn's extensive analysis and translation of portions of The Great Theatre from 2000, as well as his subsequent writing on Houbraken as a Deistic Classicist. ${ }^{17}$

By contrast, the topic of Houbraken has only recently come into focus within intellectual history and religious history in studies by Jonathan Israel who wrote briefly on the Letters of Philalethes in 2002, attributing the treatise to Willem Goeree $\left(1635^{-1711)} \cdot .^{18}\right.$ Then, by 2006 , having acquainted himself with recent art historical documentation and literature, he explored Houbraken as the author of this work and therefore as a "Radical Enlightenment" thinker. ${ }^{19}$ There is much ongoing debate among intellectual historians regarding this concept of Radical Enlightenment: Israel initially championed rationalism in early Enlightenment heterodox thought as a step toward secularism and atheism, while views since then (including some of his own writings) have challenged or softened this stance to recognize often deeply religious but heterodox impulses within early radical Enlightenment writings from members

15 On reception history see Horn, Golden Age Revisited (see above, n. 2), 1: 621-634.

16 On this, see Hendrik J. Horn, "Deistic classicism in Arnold Houbraken's Life of Rembrandt," in Rembrandt 2006: Essays, ed. Michiel Roscam Abbing (Leiden, 2006), 251-266, there 262.

17 Michiel Roscam Abbing, "Houbrakens onbeholpen kritiek op de Rembrandt-ets 'De zondeval' (B 28)," De Kroniek van het Rembrandthuis 2 (1994), 14-25; idem, Rembrandt toont sijn konst: Bijdragen over Rembrandt-documenten uit de periode 1648-1756 (Leiden, 1999), 129-150; Horn, Golden Age Revisited (see above, n. 2), passim, especially 1: 40-68. The first complete English translation of The Great Theatre, translated by Horn and integrated into the database by Rieke van Leeuwen, is forthcoming with RKD Studies.

18 Israel, Radical Enlightenment (see above, n. 9), 432-433 and n. 197-189.

19 Ibid., 428-429 and n. 85. See also Jonathan Israel, "Spinozistic Popular Radicalism in the Dutch Art World of the Later Golden Age," in De tienduizend dingen: Feestbundel voor Reinier Salverda, ed. Hanno Brand (Leeuwarden, 2013), 129-144; and Israel, "Popularizing Radical Ideas" (see above, n. 7), 270-291. 
of dissenting groups and minority religious movements. ${ }^{20}$ While debate goes on about this topic, presently scholars in both art history and intellectual history-often within different historiographical and methodological trajectories-have demonstrated that Houbraken's writings place him squarely among the heterodox and controversial Enlightenment writers of the age. Horn in particular has demonstrated that not only Houbraken's theological / theoretical treatises but also Houbraken's Great Theatre deserve consideration for their relevance to Enlightenment thought. Horn calls The Great Theatre a "monument to the non-conformist Early Enlightenment in the Netherlands." ${ }^{21}$

To date, Hendrik Horn's useful nine-page assessment of the representation of religion in his two-volume tome on The Great Theatre stands as the only study on the theme of religion in Houbraken's artist biographies. ${ }^{22}$ Some key assessments on religion by Horn bear repeating, while others will be extended and adjusted in this paper. In the pages that follow, attention will be focused more specifically upon Houbraken's representation of heterodox artists and the experiences of artists from religious minority groups. Following a review of Houbraken's own background-in particular, his little-studied Dordrecht Mennonite years, we will turn to Houbraken's treatment of Mennonitism in The Great Theatre, including his representation of various Mennonites that he knew personally; after that, this study will broaden out to explore his incorporation and representation of other unconventional Christians who were artists. Houbraken's own opinions and nonconformist theological leanings are articulated here and there within this array of artist biographies, sometimes evidenced in his theoretical asides, sometimes highlighted via the other heterodox thinkers he cites, and sometimes embedded in the anecdotes about art and religion that he chooses to feature within The Great Theatre.

20 In response to Israel, see for example, Douglas Shantz's argument for the reinvigorating role of Pietism and of "vital, Radical Christianity" in the early Enlightenment: Douglas H. Shantz, "Religion and Spinoza in Jonathan Israel's Interpretation of the Enlightenment," in Religious Minorities and Cultural Diversity in the Dutch Republic, ed. August den Hollander, Alex Noord, Mirjam van Veen, and Anna Voolstra (Leiden, 2014), 208-221, there 221 and passim. For further assessment of this historiography, Annelien de Dijn, "The Politics of Enlightenment: From Peter Gay to Jonathan Israel," The Historical Journal 55 (2012), $785^{-8}$ o5.

21 Horn, Golden Age Revisited (see above, n. 2), 1: 291. For more about the role of Mennonites in the Dutch Enlightenment, see Michael Driedger, "Aufklärung," in MennLex v: Mennonitisches Lexikon Online, ed. Hans-Jürgen Goertz (2010-2020) (https://www.mennlex.de/ doku.php?id=top:aufklaerung).

Horn, Golden Age Revisited (see above, n. 2), 1: 283-291. 


\section{2 \\ Houbraken's Early Years in Dordrecht: The Flemish Mennonite Milieu}

The city of Dordrecht was a stronghold of Dutch Reformed theology following the establishment of the Reformation in the sixteenth century and then the Synod of Dordrecht (1618-1619), which settled the power struggle between the orthodox Dutch Reformed and the Remonstrants. However, the Flemish Mennonites, among whom Houbraken's childhood and youth were spent, also had a presence in the city as of the mid-sixteenth century. ${ }^{23}$

The Flemish Mennonite church in Dordrecht was at once a bastion of Mennonite theological conservatism and a meeting place that was home to several of Dordrecht's innovative artists, writers, and thinkers. Among the writers were martyrologist and minister Thieleman Jansz van Braght (1625-1664) and city historian Matthijs Balen (1611-1691), whose grandson Houbraken would later teach as an art pupil. ${ }^{24}$ The congregation also included artists and writers among the Van Hoogstraten family; among these, Houbraken's teacher, the Rembrandt pupil Samuel van Hoogstraten (1627-1678), who was excommunicated in 1686 for marrying outside the Mennonite congregation (buitentrouw) after several other warnings for misdemeanors, like getting caught wearing a sword. ${ }^{25}$ Houbraken also collaborated with many of the writers in the Van Hoogstraten family throughout his career. ${ }^{26}$ Furthermore, Houbraken must have known the fellow Mennonite and artist Willem Beurs (1656-1700), who was almost the same age: Beurs was baptized in $1676,{ }^{27}$ and also overlapped with Houbraken in his time as an art pupil of Willem van Drielenburg (1632-

23 On early Anabaptism there, see Albert F. Mellink, De Wederdopers in de noordelijke Nederlanden 1531-1544 (Groningen, 1954), 28-31. Also see Karel Vos, "Dordrecht (Zuid-Holland, Netherlands)," in The Mennonite Encyclopedia, 5 vols. (Hillsboro, KS, 1955-1959, 199o); due to COVID-19, this and other articles from the Mennonite Encyclopedia will be cited in their digital form in the Global Anabaptist-Mennonite Encyclopedia Online (hereafter GAMEO); for this article on "Dordrecht," see https://gameo.org/index.php?title=Dordrecht_(ZuidHolland,_Netherlands). In most cases GAMEO reproduces the same articles as are available in print.

24 On the grandson by the same name, see Pieter A. Scheen, "Balen, Matthijs," in Lexicon Nederlandse beeldende kunstenaars, 1750-1880 (The Hague, 1981), 23.

25 He was banned in 1656. Michiel Roscam Abbing and Peter Thissen, De schilder en schrijver Samuel van Hoogstraten 1627-1678: Eigentijdse bronnen en oeuvre van gesigneerde schilderijen (Leiden, 1993), 50, doc. nr. 43 .

26 Francois, and Jan and David left the Mennonites. Peter Thissen, Werk, netwerk en letterwerk van de familie Van Hoogstraten in de zeventiende eeuw (Amsterdam, 1994), passim.

27 The baptismal record is in the Regionaal Archief Dordrecht: 11 Doop-, trouw- en begraafboeken van Dordrecht, inventarisnr. 78 , page $89(1676)$. 
1687). ${ }^{28}$ All of these individuals are discussed, quoted, or cited in The Great Theatre, offering a window into Houbraken's Mennonite milieu.

The son of a cloth darner, Houbraken did not have the opportunity for an extensive conventional education. However, reading and theological study were a component of his upbringing within the Mennonite community in Dordrecht: Mennonites placed great emphasis on scriptural study among congregants. Furthermore, the congregation offered useful career networks despite being a minority faith group. These socio-religious realities were recognized at the time. For example, in the long satirical poem about Houbraken's life, Lyris, the anonymous author-probably the aggravated Jan van Hoogstraten, following a very public row over a publication collaboration on the life of Paulwrites this: "His education wanted for nothing in the way of power or assistance, / For Menno Symon's Church consulted on this ..."29

The theology of the Dordrecht Mennonite group was conservative, falling in with the confession-supporting viewpoints of the Zonists during a time when major lines were being redrawn across the Dutch Republic among the different denominational branches of Mennonitism. ${ }^{30}$ From early on, Dordrecht was important to Mennonite development as the site where the Dordrecht Confession was finalized in 1632 . This confession unified a variety of Mennonite factions, including the Old and Young Flemish groups in Dordrecht, who subsequently called themselves the United Flemish Congregation. ${ }^{31}$

Later, Thieleman van Braght was a significant figure in the maintenance of Mennonite confessionalism and staunch theological conservatism within this community, serving as minister there from 1648 until his death when Houbraken was a young child. Van Braght chaired the Mennonite Synod of

28 Houbraken says he was with Van Drielenburg in 1669. See De groote schouburgh (see above, n. 1), 1:130-131. Other sources suggest he was there in 1672. See Horn, Golden Age Revisited (see above, n. 2), 1: 19-20.

29 [Attributed to Jan van Hoogstraten / Joan de Haes], Lyris Opper Rym- en schilderbaaz Nieuw opgestane Brievenschryver, En nu volmaakt Zwartekonstschraper an't Y. Boertend Heldendigt (Breda: Cornelis Setsers, n.d. [ca. 1713-1714]). Translation from Horn, Golden Age Revisited (see above, n. 2), 1: 19; on the publication of Lyris see ibid., 18-19, 42-46; also, Hofstede de Groot, Arnold Houbraken (see above, n. 5), 458-461.

30 This major schism began in Amsterdam and was known as the Lammerenkrijgh (War of the Lambs). See H.W. Meihuizen, Galenus Abrahamsz, 1622-1706: Strijder voor een onbeperkte verdgraagzaamheid en verdediger van het Doperse spiritualisme (Haarlem, 1954), 54-98; and Michael D. Driedger, Obedient Heretics: Mennonite Identities in Lutheran Hamburg and Altona during the Confessional Age (Aldershot and Burlington, VT, 2002), especially ch. 3: "The Confessionalist Strategy of Flemish Leaders."

31 Karl Koop, Confessions of Faith in the Anabaptist Tradition, 1527-1660 (Kitchener, on, 2006), 308-309. 
Leiden in June 1660, which came down firmly against the looser views on confessionalism held by the Collegiant sympathizer, medical doctor, and Mennonite minister Galenus Abrahamsz de Haan (1622-1706). ${ }^{32}$ When Van Braght published his important Mennonite martyrology, Bloedig tooneel of martelaarspiegel der Doops-gezinde [Bloody Theatre or Martyrs Mirror of the Mennonites-hereafter, Martyrs Mirror] (166o), he reprinted three Mennonite confessions of faith including the Dordrecht confession within it - a polemical move upholding the position of the confessionalists. ${ }^{33}$

It is evident, in short, that a confession-oriented church culture persisted among the Dordrecht Mennonites at the time of Houbraken's youth. It is also likely that Houbraken's theological upbringing was shaped by ideas in Van Braght's popular catechism book for Mennonite children, School der zedelijke deugd, geopent voor de kinderen der Christenen (1657) [School of Moral Virtue Made Plain for the Children of Christians] ${ }^{34}$ Over the course of the early modern period, responsibility for educating children in Mennonite beliefs shifted from the parents to the church body, and in the second half of the seventeenth century it became the common practice for Mennonite youth to attend a church group that led up to the candidates' decision on adult baptism. ${ }^{35}$ Houbraken mentions attending what seems to be such a group in his biography of Samuel van Hoogstraten, where he writes,

It happened (as I was also attending church discussions or gatherings [Kerkkollegie of 't zamenkomst] at that time) that through carelessness I left the topic to be discussed the following Sunday, written on a piece of paper, on the shelf of my easel instead of putting it away elsewhere. My master picked it up and read the contents, which were as follows: "if Adam's business [the Fall] was contingent business or one preordained

32 H. Westra and Nanne van der Zijpp, "Braght, Tieleman Jansz van (1625-1664)," in GAMEO (see above, n. 23), https://gameo.org/index.php?title=Braght,_Tieleman_Jansz_van_(16251664). On Galenus as an important figure in Dutch Collegiantism, Andrew Fix, Prophecy and Reason: The Dutch Collegiants in the Early Enlightenment (Princeton, 1991), 84-112; Francesco Quatrini, "Adam Boreel and Galenus Abrahamsz: Against Constraint of Consciences: Seventeenth-Century Dissenters in Favor of Religious Toleration," History of European Ideas 44 (2018), 1127-1140, there 1134-1136 and 1138-1139.

33 See Driedger, Obedient Heretics (see above, n. 3o), ch. 3; and David L. Weaver Zercher, Martyrs Mirror: A Social History (Baltimore, 2016), passim, especially $45^{-88 .}$

34 Van Braght's catechism book was particularly popular: it enjoyed eighteen editions. Westra and Van der Zijpp, "Braght, Tieleman Jansz van" (see above, n. 32 ).

35 Erland Waltner, Nanne van der Zijpp, Harold S. Bender, and James H. Waltner, "Baptismal Instruction," in GAMEO (see above, n. 23), https:/gameo.org/index.php?title=Baptismal _Instruction. 
by God." He put it back down. But before he left me he said: "when I was young I did the same and thought it was time well-spent. But when I became wise, I discovered it was time wasted." 36

By the time Houbraken started studying with Van Hoogstraten, the latter had been banned from the Mennonite church for nearly ten years while Houbraken was just a few years away from his own choice to receive adult baptism in the Mennonite congregation. This timeline supports the hypothesis that the anecdote is a reminiscence on the Dordrecht Mennonite church's youth discussion class that both he and Van Hoogstraten had gone through. Incidentally, Houbraken makes no reference to the Mennonite theological answer on free will that orthodox Reformed, with their belief in predestination, would have found heterodox. ${ }^{37}$ Houbraken's later writings would also suggest that he never picked up a belief in predestination: for example, Houbraken writes in the Letters of Philalethes: "and thus, I conclude, if man does not have complete free will, how is it conceivable that he can sin?"38

Houbraken was baptized at the age of 20 on 30 June 168 o by Seger Dircksz de Pot, who was the congregation's preacher since $1675 .^{39}$ The precise date of Houbraken's break with the Mennonite congregation is unclear, but it is most likely linked to the date of his marriage to the non-Mennonite Sara Sasbout, daughter of the city surgeon, on 3 July 1685 . The Dordrecht Mennonites continued to uphold a strict position on the ban and used it in cases of buitentrouw; this was also firmly laid out in the Dordrecht Confession. ${ }^{40}$ Since no

36 English translation from Hendrik J. Horn, "Appendix of References to Samuel van Hoogstraten," in The Universal Art of Samuel van Hoogstraten (1627-1678): Painter, Writer, and Courtier, ed. Thijs Weststeijn (Amsterdam, 2013), 241-258. This is a better translation than the one in Horn's Golden Age Revisited, where he translates "Kerkkollegie of't zamenkomst" as "Church lectures or confirmation." The Mennonites do not undergo confirmation. Houbraken, De groote schouburgh (see above, n. 1), 2: 164.

37 See for example, Dordrecht Confession points 1 and 2, on the fall of humankind and the restoration of humankind, translated in Koop, Confessions of Faith (see above, n. 31), 295296.

38 Horn's translation from Anonymous [Houbraken], Brieven van Philalethes ... (Amsterdam: P. Boeteman, n.d. [1712]), 2: 16-20. Horn, Golden Age Revisited (see above, n. 2), 1: 5 o.

39 Jan Leendert Dalen, "Arnoldus Houbraken," Nieuwe Rotterdamsche Courant (26 July 1933), 2, columns 2 and 3; Horn, Golden Age Revisited (see above, n. 2), 1: 17 and 2: 711, n. 2-44. Seger Dircksz, who baptized him, was selected to be a Mennonite leraar (teacher) on 3 May 1675. Private email correspondence with Ruud Lambour, October 8, 2020.

40 Jaap Brüsewitz and M.A. Krebber, eds., Confessie van Dordrecht 1632 (Amsterdam, 1982), 50; Samme Zijlstra, Om de ware gemeente en de oude gronden: Geschiedenis van de dopersen in de Nederlanden, 1531-1675 (Hilversum, 2000), 395 and n. 56 . 
record has come to light of Houbraken's ban for buitentrouw, it is likely that Houbraken chose for himself to cease membership. Horn is probably correct in positing that the Mennonite community of Dordrecht objected in some way to Houbraken's marriage: banns of marriage were published on 13 May 1685 and the marriage was announced on 20 May 1685; the wedding itself took place on 3 July 1685 . At that time, the period between the banns and wedding was normally three weeks, while here it took seven weeks. This could mean that concerns were raised about the union. ${ }^{41}$ No archival record has been found of Houbraken's switch of membership to the Dutch Reformed of Dordrecht, but the couple had their ten children baptized as infants in the Reformed Church. ${ }^{42}$ The concern later among Reformed authorities regarding Houbraken's writing, and especially the investigation and chastisement of Houbraken by the Reformed consistory in Amsterdam in 1713, points to his switch of membership to the Reformed church sometime before then. ${ }^{43}$

Houbraken remained in Dordrecht among the Reformed for over twenty years after his marriage and (likely) his formal departure from the Mennonite congregation in or around 1685. In The Great Theatre biography of Abraham Staphorst, Houbraken discusses the artist's father as "a diligently virtuous and godly teacher, who guided the Reformed Church in Dordrecht by teaching and example for years." 44 Houbraken gets the minister's name wrong, calling him "Johannes," but it was Casparus Staphorstius (1594 or 1595-1679) who was the father of Abraham Staphorst and a Reformed minister first in Edam and then in Dordrecht between ${ }^{1643-1679 .}{ }^{45}$ If Houbraken was among the Mennonites until 1685, Staphorst would not have been his own minister so he may not have met him personally or known him very well, though he would likely have heard of the recently deceased minister from Reformed congregants of Dordrecht.

Houbraken maintained contact later on with Mennonites and Collegiants in circles less conservative than his original Dordrecht congregational context.

$41 \quad$ Horn, Golden Age Revisited (see above, n. 2), 1: 31.

42 On Houbraken's children, see P.J. Frederiks, “Arnold Houbraken en zijne kinderen," Obreen 6 (1884-1887), 332-337.

43 Horn, Golden Age Revisited (see above, n. 2), 1: 59 and 2: 729, n. 2-270; and Ruud Lambour, "Het doopsgezind milieu van Michiel van Musscher (1645-1705) en van andere schilders in zeventiende-eeuws Amsterdam: een revisie en ontdekking," Doopsgezinde Bijdragen 38 (2012), 223-258, there 236. Those who were church members fell under the jurisdiction of the church consistory for chastisement (others did not).

44 It is noteworthy that he uses the typically-Mennonite term of leeraar (teacher) to refer to this Reformed minister. Houbraken, De groote schouburgh (see above, n. 1), 1: 248-249.

45 A. Bredius, "De Schilder Abraham Staphorst," Oud-Holland 55 (1938), 87-92, there 87-88. 
As we will see, Mennonites and Collegiants also played a role in publishing and upholding interest in Houbraken's writing after his death.

\section{$3 \quad$ Houbraken's Representation of Mennonites and Their Stories in The Great Theatre}

\subsection{Dordrecht Mennonites}

Though Houbraken left the Dordrecht Mennonite milieu, several people, publications, and stories from his Dordrecht Mennonite years find their way into his Great Theatre. Houbraken knew written works of his congregation's esteemed martyrologist and historian. He cites both Van Braght's Martyrs Mirror and Balen's 1677 history of Dordrecht (wherein Balen also in turn cites Van Braght) in the biography of Dordrecht artist and Mennonite martyr Jan Woutersz van Cuyck (ca. 1540-1572). ${ }^{46}$ As Van Braght, Balen, and Houbraken relay, Van Cuyck was a painter and glass engraver from Dordrecht, and he was burned at the stake alongside Adriaentje Jans of Molenaarsgraaf in Dordrecht in 1572. The three authors all include the infamous local story of Cuyck's commission from the Sheriff of Dordrecht, Jan van Drenckwaart, to portray him as King Solomon for a painting of the judgement of Solomon (1 Kings 3:26).$^{47}$ Based on the page numbers Houbraken gives in his citation of Van Braght, "590 en [and] 628," he seems to have known both the 1660 and 1685 edition - he indeed lists the 1685 pagination first, while the pagination " 628 " corresponds (with an apparent printing error) to the earlier 166o edition. ${ }^{48}$

46 Houbraken writes, "Zie [see] Matt. Balens beschryvinge van Dordrecht p. 841. en 't [and the] Bloedig Tooneel der Doopsgezinden, pag. 59o. en 628." Houbraken, De groote schouburgh (see above, n. 1), 1: 51 .

47 Nanne van der Zijpp, "Jan Woutersz van Cuyck (d. 1572)," GAMEO (see above, n. 23), https://gameo.org/index.php?title=Jan_Woutersz_van_Cuyck_(d._1572). Since discovery of a tondo featuring Solomon's judgement in the late nineteenth century, this artwork has been attributed to Van Cuyck and associated with this story. See G.H. Veth, "Aanteekeningen omtrent eenige Dordrechtsche schilders," Oud Holland 7 (1889), 298-311, there 307. The actual painting is likely lost: recent technical analysis at the Dordrecht Museum suggests that the tondo is probably from the early seventeenth century not the sixteenth century. Personal correspondence with Dordrecht Museum curator, Sander Paarlberg, October 15, 2020.

48 Cuyck's account begins on page 59 o in the 1685 illustrated edition; it begins at the very end of page 617 in the 166 o edition. The reference to page 628 appears to be a minor typo: in the 166o edition, 628 is in the middle of the Van Cuyck "brieven," while page 618 is the first full page of the Van Cuyck account. Thieleman Jansz van Braght, Het Bloedig Tooneel, of Martelaers Spiegel der Doops-gesinde of Weereloose Christenen ... (Dordrecht: Jacob Braat for Jacobus Savery, 166o; reprinted in Amsterdam: J. Vander Deyster, et al., 1685). 
Houbraken also writes about Dordrecht congregation member Dirk van Hoogstraten (1596-1640) - the silversmith and painter who was the father of his teacher, Samuel-fleeing from a German-Catholic region because he could not in good conscience swallow the host in a Catholic mass. ${ }^{49}$ Also relevant is the biography of Dirk Raphaelsz Camphuysen (1586-1627), to be discussed below.

Furthermore, Houbraken provides the only early biography of his contemporary Willem Beurs. He outlines Beurs's humble origins as son of a shoe shiner, and identifies his skill as a landscape painter, and later portraitist, as well as his move to Amsterdam. ${ }^{50}$ He describes the artist's subsequent work teaching youths and writing a painter's manual, from which Houbraken deigns to transcribe an entire page on painting tubers for still lifes. However, Houbraken incorrectly discusses and makes puns about the artist's move to "Grol," while Beurs actually moved to the Hanseatic city of Zwolle in Overijssel..$^{51}$ This confusion would suggest the two lost touch after Beurs moved away.

\section{2 $\quad$ Lamists and Collegiants}

Houbraken moved to Amsterdam after 1709, explaining in the General Guidelines (1712) that he was "encouraged in his intellectual pursuits by Brother Collegiants ... in Amsterdam and Rotterdam ... where [he] attended many heated disputes."'52 It may be via these Collegiant networks that Houbraken came to know of Galenus Abrahamsz (though he had died a few years before Houbraken's arrival in the city) and where he potentially met many other Lamist Mennonites who were involved with the Collegiants. ${ }^{53}$ Several Lamists and Collegiants are cited or biographized in The Great Theatre.

49 Houbraken, De groote schouburgh (see above, n. 1), 1: 160-161; Horn, Golden Age Revisited (see above, n. 2), 1: 239-240, 286.

$5^{\circ}$ Beurs appears to have become a Remonstrant. His children were baptized by the Remonstrant minister Gerardus Brandt. Robert-Jan te Rijdt, "Willem Beurs (Dordrecht 1656tussen 1694 en 1713)," Delineavit et Sculpsit 45 (2019), 63-69, there especially 65-66.

$5^{1}$ In 1687 he moved to Zwolle. It appears to be a typo or possibly a mistaken reference to a tiny place called Zwolle near Groenlo (Grolle). Beurs himself writes on his move to Zwolle (Overijssel), Wilhelmus Beurs, De groote waereld in 't kleen geschildert, of schilderagtig tafereel van's Weerelds schilderyen. Kortelijk vervat in ses boeken. Verklarende de hooftverwen, haare verscheide mengelingen in oly en der zelver gebruik (Amsterdam: Johannes and Gillis Janssonius van Waesberge, 1692), 2, 4.

52 Horn's translation from Anonymous [Houbraken], De gemeene leidingen ... (Amsterdam: printed for the author, 1712; reprinted 1729), 15. Horn, Golden Age Revisited (see above, n. 2), 1: 41 and 2: 721, n. 2-166.

53 Fix, Prophecy and Reason (see above, n. 32), 84-112. 
Among his acquaintances and writing collaborators was Lamist Mennonite and author Gezine Brit, who also wrote the poetry for his posthumously published emblem book. Houbraken had asked his friend Jacob Zeeus to provide poetry, but the latter died in 1718 without completing the task; therefore, he appealed to Brit, and she produced the poems to accompany his $57 \mathrm{emblems}$ and descriptive texts. ${ }^{54}$ These emblems were moralizing in nature and even included some neo-Stoic themes. ${ }^{55}$

Brit wrote many songs for Mennonite song books, translated out of Latin and English, and wrote moralizing poetry regarding the importance of a Christian upbringing for children. She also wrote a long pastoral laudatory poem in 1686 about the artworks by the celebrated paper-cutter, Lamist Mennonite Joanna Koerten (1650-1715). ${ }^{56}$ Houbraken quotes the entirety of Brit's poem in The Great Theatre within the particularly long biography he offers on Koertena compliment to both Mennonite women. Brit's poem showcases Koerten's papercut portrait of Galenus Abrahamsz, offering praise for him using a thick web of allegory. ${ }^{57}$ Houbraken, who provides footnotes on the whole poem, clearly understood the allegory: he identifies "Waarmond" in a footnote as "Galenus Abrahamsz, the Mennonite teacher and M. [medical] doctor."58 This is a play on words regarding Brit's positive view of Galenus as "True-mouth," or truth speaker and likely also a pun on Warmond, the place where the Collegiants originated.

Houbraken never explicitly refers to writers or artists as Lamists or as Collegiants in The Great Theatre, but he does mention Collegiant gatherings in the biography of the Mennonite Jan van Nikkelen (1655/56-1721). Nickelen was a baptized member of Amsterdam's united Flemish and Waterlander congregation; he first studied art with his father Isaak van Nickelen (1632/33-1703), a Waterlander Mennonite from Haarlem. ${ }^{59}$ Isaak is not treated separately by

54 Klaas van der Hoek, et al., "Gezine Brit," in Gedoopt: Vijf eeuwen doopsgezinden in Nederland (Oostzaan, 2011), unpaginated.

55 Horn, Golden Age Revisited (see above, n. 2), 1: 70.

56 Brit was baptized in the Lamist congregation of the Lam en Toren in 1688 but was married to a Zonist Mennonite. She worked on several occasions with other Mennonite poets including Lamist Adriaan Spinniker (1676-1754) and Zonist minister and writer Hermannus Schijn (1662-1727). See Van der Hoek, et al., "Gezine Brit," (see above, n. 54).

On Koerten's oeuvre, see Joke and Jan Peter Verhave, "Joanna Koerten en haar Schaar van bewonderaars: Ter gelegenheid van haar 3 ooste sterfaar en de tentoonstelling 'Ode aan een ambacht,' in Museum Willet-Holthuysen, Amsterdam," Doopsgezinde Bijdragen 42 (2017), 147-180.

58 Houbraken, De groote schouburgh (see above, n. 1), 3: 302.

59 On Jan's membership, Lambour, "Het doopsgezind milieu van Michiel van Musscher" (see above, n. 43), 235-236 and n. 24; on Isaak's membership, ibid., 237 and n. 33. 
Houbraken, though he notes in the biography of Jan that the father was a skilled "Church painter in the manner of van Vliet": indeed, this Mennonite specialized in painting whitewashed Reformed church interiors. ${ }^{60}$ Houbraken outlines Jan van Nickelen's excellent education and notes, in what is also the only reference to Socinians in The Great Theatre, that the artist "sharpened his wit" with "those that people call Mennonite or Socinian Disputants." ${ }^{61}$ It is surprising that Houbraken does not mention more specific terminology here, given his own Collegiant and Mennonite ties. However, as following examples will demonstrate, this penchant for avoiding giving explicit references to artists' religious affiliation persists throughout many accounts in The Great Theatre.

\subsection{Mennonites in The Great Theatre: Observations on Terminology}

Many more Mennonites cross the stage in Houbraken's Great Theatre. The Amsterdam inventor and cityscape painter Jan van der Heyden (1637-1712) and members of the Van der Vinne family in Haarlem were artists and also actively involved in their Mennonite congregations as deacons; Houbraken describes these and several other Mennonite artists' successful careers but does not mention their religious affiliation at all. ${ }^{62}$ By contrast, Anabaptist or Mennonite ties are central to accounts of David Joris (1501-1556) and Michiel van Mierevelt (1566-1641), to be discussed below, and to the biography of successful Rembrandt pupil Govert Flinck (1615-166o). Houbraken describes the young Flinck's desire to be an artist while his strict Mennonite parents disprove; ${ }^{63}$ it is only after the Waterlander Mennonite minister and artist / art dealer, Lambert Jacobsz from Leeuwarden ["Mennonist, of Doopsgezind Leeraar te Lewaarden"] stops in Cleve on his preaching tour that Flinck's strict parents are impressed and allow their son to study art under his tutelage. ${ }^{64}$ Houbraken explains that Flinck was roommates in Leeuwarden with the artist Jacob Adriaensz Bakker

6o Houbraken, De groote schouburgh (see above, n. 1), 3: 265. Though not mentioned, Jan's daughter was the successful still life painter Jacoba Maria van Nickelen (ca. 169o-1749).

61 Lamists and Collegiants were often labelled as "Socinians" by their opponents, including conservative Mennonites and Reformed; used polemically, the reference to the antiTrinitarian movement was meant to imply heresy and atheism. See Francesco Quatrini, Adam Boreel (1602-1665): A Collegiant's Attempt to Reform Christianity (Leiden, 2021), 88; and also see Quatrini's essay in this Special Issue of Church History and Religious Culture.

62 For an overview of archival details on many Mennonite artists, see Lambour, "Het doopsgezind milieu van Michiel van Musscher" (see above, n. 43), passim; on Van der Heyden and on the Vincent Laurens van der Vinne, ibid., 235 and n. 19.

63 This negative stance on art was present among Mennonites in some parts of Europe, but atypical of Dutch Mennonites; almost all Dutch groups had no qualms about the artists' profession or about art collecting for their homes.

64 Houbraken, De groote schouburgh (see above, n. 1), 1: 17-27, there especially 19-20. 
(also from a Mennonite home, ${ }^{65}$ though Houbraken does not mention this), and that once both were advanced in their skills they departed together for Amsterdam; he notes that there Flinck quickly found patronage among his well-off extended family, and he decided to study for a year with Rembrandt (he does not mention that Flinck's family were Waterlander Mennonites in Amsterdam, and that Rembrandt's art dealer was the Waterlander Hendrik Uylenburgh who was also in contact with Lambert Jacobsz). ${ }^{66}$

As Horn astutely notes, most artists' faiths-Reformed, Catholic, Remonstrant, or otherwise-are not specifically identified by Houbraken unless directly linked to the story at hand. ${ }^{67}$ This point can be pushed even further: in many stories, even when religion is a key factor of an anecdote, the specific religious affiliations of the artists are not always given or are only circumstantially implied. For instance, Dirk van Hoogstraten was clearly not a Catholic, given the anecdote above; however, Houbraken does not specify that he was a Mennonite. The martyr Van Cuyck's affiliation is only implied due to the footnote citing Van Braght's Mennonite martyrology as a source. Likewise, Jan van Nikkelen's Mennonite affiliation is not explicitly given, and Houbraken does not specify Flinck's own changing faith affiliations. ${ }^{68}$ These are a few of many examples like this, suggesting Houbraken often focuses on art and, as Horn argues, on the trouble of religious tension and toleration in general, rather than taking sides in inter-denomination apologetics and polemics. ${ }^{69}$

Though Houbraken knew the Mennonite tradition well, he did not bother himself with intra-denominational nomenclature politics by distinguishing in his word selection between members of more liberal-minded groups who preferred to be called "Doopsgezinden" [baptism-minded people] and members of more conservative and confession-bound groups who preferred to be called "Mennoniten" after Menno Simons. ${ }^{70}$ In his writing, he applies several relevant terms-“Mennonisten," "Mennoniten," and "Doopsgezinden" — without strict dif-

65 Ibid., and Lambour, "Het doopsgezind milieu van Michiel van Musscher" (see above, n. 43), 235 and n. 19.

66 See Friso Lammertse and Jaap van der Veen, Uylenburgh \& Son: Art and Commerce from Rembrandt to De Lairesse, 1625-1675 (Amsterdam, 2006), passim.

67 Horn, Golden Age Revisted (see above, n. 2), 1: 285 .

68 Though Flinck grew up in a Mennonite family, he chose to be baptized as an adult among the Remonstrants. See Lambour, "Het doopsgezind milieu van Michiel van Musscher" (see above, n. 43), 235 and n. 19.

69 Horn, Golden Age Revisited (see above, n. 2), 283-291.

70 See Piet Visser, "Mennonites and Doopsgezinden in the Netherlands, 1535-1700," in $A$ Companion to Anabaptism and Spiritualism, 1521-1700 [Brill's Companions to the Christian Tradition 6], ed. John D. Roth and James M. Stayer (Leiden, 2007), 299-347. 
ferentiation..$^{71}$ A notable example is his choice to call Galenus Abrahamsz a Mennonite minister, when the Lamist group in Amsterdam and their sympathizers elsewhere preferred to be called Doopsgezinden.

While he uses Mennonite and Doopsgezind references interchangeably, Houbraken is accurate in that all those who are called by either of these names are indeed members among the Mennonites / Doopsgezinden. ${ }^{72}$ Furthermore, as the discussion on David Joris below will demonstrate, he is very particular with his relegation of the term "Wederdooperen" [Re-baptizers / Anabaptists] only for use in reference to the controversial Münsterite Anabaptists. ${ }^{73}$ He thereby distances the Mennonites / Doopsgezinden from early insurrectionist branches of Anabaptists in a linguistic convention which takes its cue from any number of Dutch Mennonite authors, like Van Braght or Hermanus Schijn (1662-1727), who always took care to make a strong distinction between the Mennonites and the early revolutionary Wederdopers in their apologetics, pamphlets, and church histories of the seventeenth and eighteenth centuries.

Though The Great Theatre has become a conventional art historical reference work, ${ }^{74}$ it includes many sources-including excerpts from Houbraken's own earlier controversial writings - that were, in their time, far from conventional. For example, Houbraken offers a sincere word of thanks to Balthasar Bekker (1634-1698), the author of De betoverde weereld [The Enchanted World], for freeing the Dutch Republic from superstitious beliefs about witchcraft. This occurs in his long footnote about sorcery within the biography of Jan Hakkart, where he describes Hakkert's experiences in the Swiss Mountains: the artist was captured by locals who were suspicious that his sketches were magical

71 Singular and plural versions of each of these are used. By contrast, he refers to a smaller variety of more consistent names for other groups (usually, Catholic Church [Roomsche Kerk]; Reformed Church [Gereformeerde Kerk]; or Remonstrants [Remonstranten]).

72 Houbraken does not refer to Baptists anywhere in his Great Theatre. Horn sometimes uses terms Mennonite and Baptist interchangeably; however, "Baptist" is not a historically accurate way to translate Doopsgezind. Horn, Golden Age Revisited (see above, n. 2), especially $1: 283,403$.

73 See below, n. 84 .

74 Bart Cornelis, “Arnold Houbraken's Groote Schouburgh and the Canon of 17th-Century Dutch Painting," Simiolus 26 (1998), 144-161. 
markings. ${ }^{75}$ In the biography of Augustinus Terwesten and of Job and Gerard Berkheyden, he cites from Spanish Jesuit Balthazar Gracian's El Criticón [The Critic] (referring to it from its 1701 Dutch translation by M. Smallegange as the "Ordeelaar" [sic.]), a publication for which the Jesuit author was sanctioned and exiled to Graus. ${ }^{76}$ Furthermore, Houbraken includes citations from artistart theorist and antiquarian Willem Goeree, to be discussed below.

Not only the religiously different or controversial sources themselves, but also how he cites and uses them so seamlessly are of relevance for understanding Houbraken as a dissident thinker and a champion of heterodox Enlightenment thought. Houbraken regularly uses both acknowledged art theorists, biographers, and historians, as well as writers who were very controversial in their own time, intermixing these thinkers without differentiation. In doing so he tacitly endorses and normalizes these writers. By citing and quoting authors like Bekker, Gracian, and Goeree, he undoubtedly made some orthodox readers of the early eighteenth century uncomfortable. At the same time, his inclusion of these writings, and the excerpts of his own anonymous treatises, also suggests that he expected (or hoped) that much Dutch readership would be unfazed or even interested in these unorthodox writers and writings by the early eighteenth century, as Enlightenment thinking became increasingly normalized.

Ultimately, the controversial sources in The Great Theatre do not seem to have sparked much backlash in the short or long term, since the work remained of interest and in use over subsequent centuries—albeit with some ups and downs in public interest and in scholarly opinions on historical reliability. ${ }^{77}$ In the immediate years after Houbraken's death, The Great Theatre sold well, prompting other authors like Jacob Campo Weyerman (1677-1747) to mimic his work (there, without lengthy theoretical asides), and also resulting in a second edition of The Great Theatre in $1753 .{ }^{78}$

Houbraken's whole body of publications appears to have enjoyed some sustained interest and increasing acceptability over the eighteenth century. Houbraken's Edifying Emblems was finally published posthumously in 1723 by Willem Barendts in Amsterdam. In 1729 Letters of Philalethes and General

75 Houbraken, De groote schouburgh (see above, n. 1), 3: 46-50, there 47. For a partial English translation, Horn, Golden Age Revisited (see above, n. 2), 1: 244.

$7_{6}$ Houbraken, De groote schouburgh (see above, n. 1), on Augustinus Terwesten, 3: 267-282, there 276-277; on Job and Gerard Berkheyden 3: 189-199, there 192, 193.

77 On this trajectory, see Horn, Golden Age Revisited (see above, n. 2), 1: 616-694.

78 Ibid., 1: 171 . 
Guidelines became available once again - this time under Houbraken's name. ${ }^{79}$ That same year, the Mennonite and Collegiant Isaak Tirion published a reissue of the 1723 emblem book: while a reissue indicates poor sales of the first edition, the fact that Tirion did buy up the leftover stock and reissue it would point to his anticipation of interested readers and potential profit; furthermore, a second edition of the emblem book was later published in 1767 by the heirs of the Mennonite Frans Houttuyn. ${ }^{80}$ Alongside mainstream interest in The Great Theatre, there was clearly ongoing esteem and interest for Houbraken and Brit in Doopsgezind and Collegiant circles—and potentially others—into the late eighteenth century.

Highlighting Religious Difference and Minority Experience in The Great Theatre

Joris and Other Artist Nonconformists in the Sixteenth-Century Low Countries

Like Karel van Mander before him, Houbraken offers an account of changing socio-historical context within his volumes of artist biographies through scattered observations. Houbraken's sixteenth-century accounts include details about early anticlerical reform in the Low Countries and the Eighty Years War between the Catholic Hapsburg Empire and the increasingly Protestant Dutch Provinces. A thematic leitmotif of toleration in the biographies dealing with religion is hard to miss from the outset, since Houbraken begins the volume with the biography of the great humanist Erasmus of Rotterdam, who-he is pleased to learn-occasionally made art. ${ }^{81}$ Houbraken then turns to the spiritualist David Joris, who is arguably the most (in)famous dissenter biographized in The Great Theatre. ${ }^{82}$

79 See above, n. 6.

8o Houbraken and Gezine Brit, Stichtelyke zinnebeelden; Gepast op deugden en ondeugden ... Tweede druk. Vermeerderd met eenige nagelaten gedichten van dezelfde juffrouw, 2nd ed. (Amsterdam: Heirs of F. Houttuyn, 1767). With thanks to Piet Visser for alerting me to this later edition. See also above, n. 13 .

81 Houbraken, De groote schouburgh (see above, n. 1), 1:17-19. Horn, Golden Age Revisited (see above, n. 2), 1: 92, 283 .

82 On early modern biographies of David Joris and other background, see the essay by Gary Waite in this Special Issue of Church History and Religious Culture. It is surprising that Houbraken did not include a biography of the artist and theologian, Dirk Volckertsz Coornhert. He was biographized in De Bie and in Sandrart, though they do not mention his 
Joris, who first worked as a glass painter, adopted anticlerical and antisacramentalist views in the early sixteenth century, later joining the Anabaptists and then taking on an increasingly spiritualist stance. There was a split between the followers of Menno Simons and David Joris in the late $1530 .^{83}$ By Houbraken's day there were several biographies of Joris in circulation, but Houbraken only cites Dirk van Bleyswick's history of Delft. Houbraken writes in detail on Joris within the early Anabaptist-Mennonite context, stating the following:

[Joris] was born in Delft: but in which year I do not know: it is clear that he was a Delftenaar from the preaching of the twenty-six apostles that the King of the Anabaptists [Jan van Leyden] sent out, who among other things, proclaimed to the people that since Christ, four Prophets were raised: two false, namely the Pope of Rome, and Martin Luther, and two true, namely Jan van Leyden, and David of Delft. He was (before the time that Obbe Philips appointed him as the Bishop of the Doopsgezinden of Delft) a skilled glass painter by trade; of which some vestiges in Delft in the year 1667 could be seen. ${ }^{84}$

He explains that Joris was well-spoken despite the fact that he was an actor's son, untrained in language arts (this detail about a fellow dissenter-writer-artist may have appealed to Houbraken who likewise was not privy to a classical education). ${ }^{85}$ Houbraken describes Joris's distinctive curly beard, based on which Joris's corpse was recognized when his body was exhumed to be posthumously burned for heresy. Houbraken also identifies two placards levied against Joris and mentions Joris's mother's arrest and beheading for being rebaptized. ${ }^{86} \mathrm{He}$ describes Joris's departure for Basel in 1544, where he lived in disguise as "Jan van Broek" until his death, and concludes by noting that Joris's drawings are still collected "by admirers in his memory," describing four in the collection

religious convictions. Coornhert was an advocate for religious tolerance and positioned himself against execution of those deemed heretics.

83 Gerhard Hein and Gary K. Waite, "David Joris (ca. 1501-1556)," in GAMEO (see above, n. 23), https://gameo.org/index.php?title=David_Joris_(ca._1501-1556). Unlike most articles in GAMEO, this one includes a substantial portion that is not available in the printed Mennonite Encyclopedia.

84 Houbraken, De groote schouburgh (see above, n. 1), 1: 21. The reference to the King of the Anabaptists is Houbraken's only use of the term "Anabaptists" (here "Wederdooperen" [sic.]).

85 Ibid., 1: 21-22.

86 Ibid., 1: 21-22. 
of the artist Jacob Moelaert (1649-1732) from Dordrecht. In a comment suggestive of his familiarity with examples of Joris's artwork, he notes that Joris's style brings to mind the handling of the northern Renaissance artist Lucas van Leyden. ${ }^{87}$ The final line of the biography describes The Great Theatre's accompanying portrait of Joris: "One can see his portrait in Plate A. next to that of Erasmus [;] beneath, by the appended art tools, a mask turned over by a snake (which is an emblem of his way of life) is visible." ${ }^{\prime 8}$

In the portrait print itself, which is by Houbraken's son Jacobus Houbraken (1698-1780), Joris appears alongside Erasmus and Jan Snellinck (Figure 1). While the portraits of the other two men are based on Van Dyck's set of portraits in the Iconography, Joris's print draws upon the visual tradition linked to a lost portrait by Jan Cornelisz van't Woud (d. 1615) ${ }^{89}$ To the bottom left of the portrait rondel are the box of art supplies, mask, and snake.

The imagery of the snake and mask easily brings to mind negative connotations; however, the emblem also offers some positive iconographical interpretations. Houbraken knew the Iconologia by the Italian Cesare Ripa (156o1625). ${ }^{90}$ In this illustrated guide to the symbolism in emblem books, which was republished in a Dutch translation by 1644 , Imitatione [Imitation] is personified as a woman holding a "bundle of paintbrushes" in her right hand and a "mask" in her left, with an ape by her feet: this all stands for imitation and also for art making (Figure 2). ${ }^{91}$ In the context of the Joris portrait, "imitation" conveniently describes Joris's work as artist and as a fugitive with a double life. This still leaves the snake. In biblical imagery, the snake is often negative, but not exclusively so: for example, in Matthew 10:16, Jesus urges his disciples to be "wise as serpents and harmless as doves."92 Again, the Iconologia offers what may be the best possible interpretation: the emblem of Intelligenza [intelligence] is described

\footnotetext{
$87 \quad$ Ibid., 1: 22.

88 Ibid., 1: 22.

89 On a related Rijksmuseum painting and on Christoffel van Sichem's (1581-1658) print of Joris for a series of "Arch Heretics," see R.E.O. Ekkart, "Jan Cornelisz. van 't Woudt als portretschilder," Oud Holland 103 (1989), 223-242, there 227, 232; Nina Schroeder, "Heretics and Martyrs: Picturing Early Anabaptism in Visual Culture of the Dutch Republic" (Ph.D. diss., Queen's University, 2018), 247-249. Willem Goeree published a new edition of the heretic series by Van Sichem, also including Joris, in 1677.

9o Ripa is cited in The Great Theatre elsewhere: Houbraken, De groote schouburgh (see above, n. 1), 2: 208.

91 Cesare Ripa, Iconologia, of uytbeeldingen des verstands, trans. Dirck Pietersz Pers (Amsterdam: Dirck Pietersz Pers, 1644), 350.

92 Another positive option is less likely: the snake as ouroboros represents eternity-renewal or rebirth; however, Joris's snake emblem is not the right shape for this.
} 
as a woman holding a globe in the right hand and a serpent in the other. ${ }^{93}$ The snake in this instance stands for humble learning, and wisdom:

... In order to understand lofty and weighty matters, it is necessary for one first, as a snake, to crawl on the ground, [and begin to learn] to understand lowly matters that are not so perfect as the Heavenly ones. ${ }^{94}$

The Great Theatre's positive description of Joris' manners, Houbraken's use of "Doopsgezind" rather than "Wederdoper" language to identify Joris, and Houbraken's focus on details of persecution due to religious difference suggest his sympathetic view of Joris. Indeed, Joris's spiritualist agenda would seem to be in keeping with Houbraken's own stance in favour of toleration. ${ }^{95}$

Gary Waite has shown that by the eighteenth century, Joris's reception had undergone substantial transformation among circles of Mennonites, Collegiants, and other nonconformist Enlightenment thinkers. While orthodox followers of Menno Simons in the sixteenth century did not approve of the Davidjorists, and the groups of actual Davidjorists dissipated in subsequent decades, many more branches of seventeenth-century Mennonites (particularly the more progressive Doopsgezinden) eventually appreciated the spiritualist approach that Joris had modelled. Waterlander Mennonites like Hans de Ries (1553-1638) embraced spiritualism in their theology and scriptural interpretation, and even conservative factions among the Mennonites took up his work: the Old Frisian Pieter Jansz Twisck $\left(15^{6} 5^{-1636}\right)$, for instance, used Joris's writing in his own works, albeit without indicating the source. ${ }^{96}$ Houbraken does not make his views on Joris completely transparent; but perhaps this was his intention in dealing with a dissenter who was long considered infamous and still retained negative associations in many orthodox circles.

Houbraken explores changes to the practice of art making itself during the Catholic-Reformed tensions in the North and South Low Countries of the mid-

93 She is not illustrated in the Dutch edition; not every entry is treated with an image.

94 Ripa, Iconologia (see above, n. 91), 254.

95 It is unclear how much Houbraken knew or used Joris's writings. This deserves further study.

96 Gary K. Waite, "Martyrs and Nicodemites Both? Spiritualistic and Rationalistic Currents within the Dutch Anabaptist Tradition—David Joris, Sebastian Castellio, and Pieter Jansz Twisck (1535-1648)," in Sebastian Castellio (1515-1563) —Dissidenz und Toleranz, ed. Barbara Mahlmann-Bauer (Göttingen, 2018), 423-457, especially 424; idem., "Pieter Jansz Twisck on David Joris: A Conservative Mennonite and an Unconventional Spiritualist," Mennonite Quarterly Review 91 (2017), 371-402. 


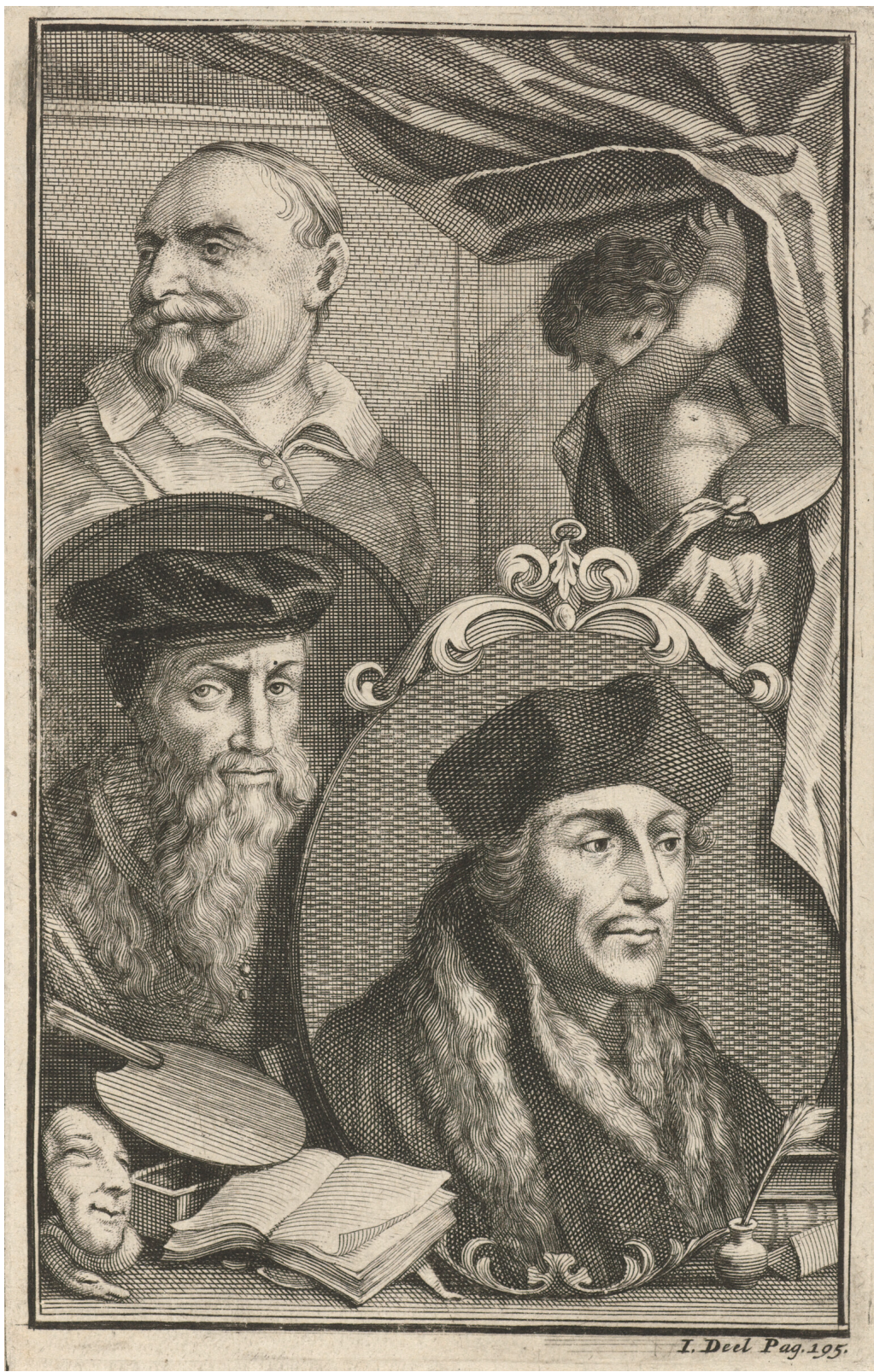

FIGURE 1 Jacobus Houbraken, Portrait ofJan Snellinck [top], David Joris [left], and Desiderius Erasmus [right], first state in 1718, engraving, in Arnold Houbraken, De groote schouburgh (Amsterdam: Printed by the author, 1718), vol. 1, pl. A. (The version of the print shown here is from a later state published in 1729) RIJKSMUSEUM, AMSTERDAM 
I M I I A T I O N E. Naevolginge, Naeboot/ingeo

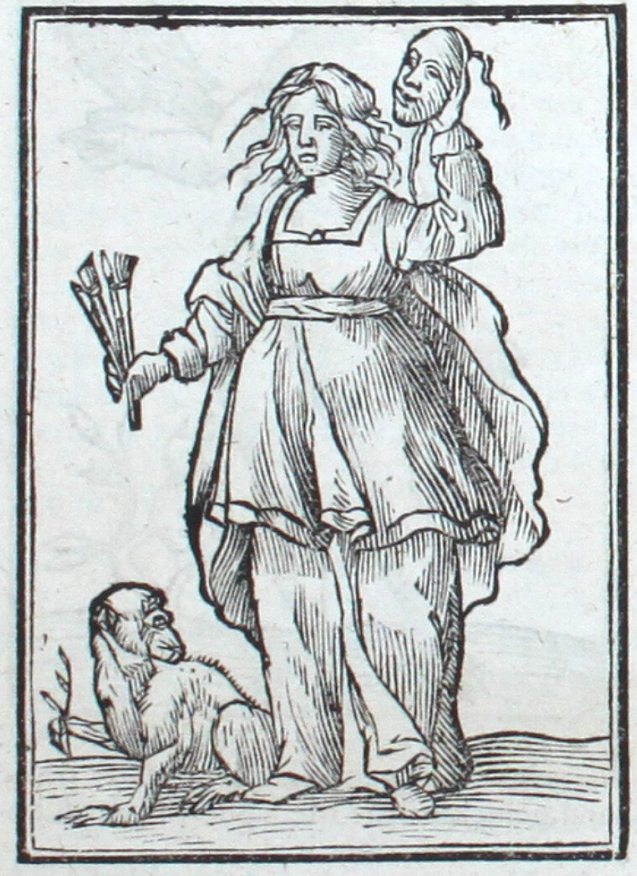

FIGURE 2

"Imitatione" in Cesare Ripa, Iconologia, of uytbeeldingen des verstands, trans. Dirck Pietersz Pers (Amsterdam: Dirck Pietersz Pers, 1644), $35^{\circ}$ UNIVERSITEITSBIBLIOTHEEK VRIJE UNIVERSITEIT AMSTERDAM, XH.OOO83.-

and later-sixteenth century in the biography of Otto van Veen (1556-1629). He explains that Van Veen lived in a time when "monastics watched aghast, ... fearful of the general decline of the chair of Rome through the preaching of John Calvin, Martin Luther, and still others, the tempers [of one against the other] grew in bitterness and strife." 97 He goes on to quote from what he names as Willem Goeree's Waereltlyke veranderingen [Worldly Changes]; Houbraken draws upon a portion of the text where Goeree is quoting from the life of Markus Geeraards of Bruges as recounted in Van Mander's SchilderBoeck, writing that Geeraards found himself "totally out of work because of the new preaching, which brought art to a complete standstill."98 Houbraken continues, "[Catholicism] was so struck by sleepiness that even the painters and sculptors were beginning to complain of bad business." Houbraken concludes that while the artist in question managed to find some illustrating work, most

97 Houbraken, De groote schouburgh (see above, n. 1), $1: 41$.

98 Ibid., 1: 41-42. See also Willem Goeree, De kerklyke en weereldlyke historien (Amsterdam: Gerardus and Jakobus Borstius, 1705), 6o9. 
contemporaries of Geeraards "saw the dark clouds of dispute, which oppressed Art," and "fled to [fresh air] elsewhere."99

Van Mander's own eye-witness accounts of this era published in 1604 offered the artist's lived perspective on this major social change. Over a century later, Houbraken's anecdotes like this one, citing third-hand from a fellow contemporaneous art theorist, demonstrate the ongoing discussion of the impact of sixteenth-century religious change on the Dutch art world; Houbraken highlights artists' migrations from the Hapsburg-Catholic south to the Reformed north (prompting the zenith of Dutch art) and also the changes that Reformed faith wrought on patronage patterns (from church to home).

Alongside the broader strokes of Protestant-Catholic tension, Houbraken also offers the account of the court portraitist Michiel van Mierevelt, who was active in this era of religious change and was guaranteed his safety, despite his religious difference, due to the demand for his artistic work. He refers to Van Mander's account of this well-known story and then quotes from Sandrart's version in the Teutsche Academie [German Academy], where the author more specifically notes that this artist was granted special permission "to practice his Mennonite religion" which "was then still intensely persecuted" at the Catholic court of Archduke Albert viı of Austria. ${ }^{100}$ Meanwhile, his story of Van Cuyck, who was executed for heresy, occurs only two biographies later, demonstrating that usefulness and artistic skill were not always enough to save a nonconformist from death.

\subsection{The Seventeenth-Century Dutch Republic and Beyond}

Most of Houbraken's seventeenth-century accounts highlight-by discussion or omission of religious themes - the pragmatic religious toleration enjoyed by most artists within the Dutch art marketplace. However, as Houbraken shows in several biographies, in artists' travels beyond the Dutch borders there were an assortment of adventures and misadventures resulting from religious difference, or simply from unfortunate instances of miscommunication-like the story of Hakkart discussed above.

Some Dutch artists who travelled outside the Dutch Republic to study and enjoy patronage opportunities in sunnier climes of France, Spain, and Italy

99 Houbraken, De groote schouburgh (see above, n. 1), 1: 42.

100 Houbraken, De groote schouburgh (see above, n. 1), 47. Joachim von Sandrart, Teutsche Academie der Edlen Bau-Bild- und Mahlerey-Künste, 3 vols. (Nuremberg: Jacob von Sandrart; Frankfurt: Matthaeus Merian, printed by Johann-Philipp Miltenberger, 1675), 2.3: $3 \mathrm{O} 2$. 
experienced difficulty in Catholic-ruled regions. ${ }^{101}$ Such stories are especially frequent among biographies of the so-called Bentvogels, Dutch artists who worked in Rome. For example, in the biography of Willem van Inghen, the group of Dutch artists were investigated by the Catholic authorities due to suspicions of heresy involving wederdoop [rebaptism].102 It is not clear whether the authorities were concerned that the artists were actually Anabaptists; however, the confusion may have arisen from the Bentvogel's practice of "christening" the new members with a nickname-a process which Houbraken consistently refers to as a "baptism" [doop] in his Great Theatre. ${ }^{103}$

Houbraken's biography of Horatius Paulyn (ca. 1644-after 1682) highlights the artist's intentional choice to travel due to his unconventional religious ties-a contrast to most of Houbraken's Bentvogel anecdotes, since those artists travelled primarily for the sake of their art and occasionally ran into difficult situations. As Houbraken writes, Paulyn "departed in the company of Jan Rote (who raved about a procession to the Holy Land), first to England, and from there to Hamburg, to recruit supporters"; the prophet, however, realized he had "made a mistake of a hundred years in his Prophetic calculations" so the group scattered "to their old cages with drooping wings." ${ }^{104}$ Rieke van Leeuwen has recently underscored the fact that this "Jan Rote" was none other than the prophetic preacher and chiliast Johannes Rothé, or Jan Rothe (1628-1702), Lord of Oud-Wulven and Wayen, and descendant of a notable Dutch patrician family. ${ }^{105}$

Within the Dutch Republic the rising religious tension between the orthodox Reformed and Remonstrants culminated in the expulsion of Remonstrant ministers by the orthodox Calvinists in 1619. This conflict is featured several times in The Great Theatre. Sometimes details are merely offered in passing as a foil to an artist's character description. Houbraken notes, for instance, that the Leiden-based Jan Lievens (1607-1674) apparently worked in such a dedicated manner in his studio that he did not notice a major scuffle outside on the streets between Remonstrants and other citizens, which became so severe that

\footnotetext{
101 For several examples, see Horn, Golden Age Revisited (see above, n. 2), 1: 283-291 and passim.

102 Houbraken, De groote schouburgh (see above, n. 1), 3: 316.

103 For example, ibid., 3: 271.

104 Houbraken, De groote schouburgh (see above, n. 1), 3: 186-187; Horn, Golden Age Revisited (see above, n. 2), 1: 291.

105 Rothe declared that after much tribulation, Amsterdam would emerge as the New Jerusalem. See Rieke van Leeuwen, "Op drift door het Rampjaar: Migratiebewegingen van Noord-Nederlandse kunstenaars 1672-1679," Oud Holland (forthcoming).
} 
the mayor called in militia to put down their rioting. ${ }^{106}$ By contrast, the decision of the Synod of Dordrecht is a focal point in the biography Dirk Rafaelsz Camphuysen (1586-1627), a Mennonite-raised artist turned-Remonstrant minister who later became a celebrated devotional poet with especially keen readership among Remonstrants, Mennonites, and Collegiants. ${ }^{107}$

Houbraken copied many details for this biography in The Great Theatre from the 1699 Amsterdam edition of the Camphuysen biography published by Jan Rieuwertsz (1617-ca. 1685). ${ }^{108}$ Houbraken describes the mother of Camphuysen, who "lived a godly life among the Mennonites [Doopsgezinden]," and he notes that her own father, Hans Mazeik who was a merchant from Gorkum, was beheaded for his faith-here copying almost verbatim from the 1699 volume but omitting the specification that he was killed by Catholics. ${ }^{109} \mathrm{He}$ shares that one day while Camphuysen (by then a Remonstrant preacher) was in his study, a large owl flew into the room and landed on his desk. Shocked, Camphuysen seized the owl and killed it, showing it to his wife downstairs. As Houbraken recounts,

[the incident was perceived as] an omen (says the Writer) that the Church-Owls ${ }^{110}$ would torment him, as happened after some days that the interdiction was pronounced, in which Kamphuizen and all those sharing his convictions were forbidden not only the Pulpit, but also the Teaching in houses, barns as well as in the open Field, at pains of seizure of body and goods. ${ }^{111}$

106 Houbraken, De groote schouburgh (see above, n. 1), 1: 297. Here he is citing from the "historian of Leiden" - presumably Jan Orlers. See also the story of Drielenburg's father. Ibid., 2: 150-151.

107 Riet Schenkeveld-van der Dussen, Een platina liedboek uit de Gouden Eeeuw: Dirck Raphaelsz Camphuysen, Doopsgezind en Remonstrant (Nijmegen, 2013), passim.

108 This was one of several editions of this work with an introductory poem by the Mennonite Petrus Rabus (166o-1702). The biography text itself is likely edited from Mennonite Barend Joosten Stol's (1631-1713) account. Rieuwertsz, too, was a Mennonite. The volume was first printed in 1683; then twice in 1699, and finally in 1723, each time by Mennonite publishers. On Stol as biographer, ibid., 11, 135 .

109 Houbraken, De groote schouburgh (see above, n. 1), 1: 123-124. Petrus Rabus, Het leven van Dirk Rafelsz. Kamphuizen (Amsterdam: Jan Rieuwertsz, 1699), 14.

110 Owls, as nocturnal animals, were often used at this time as a symbol of evil or blindness. Several polemical illustrations about the Synod of Dordrecht also use the owl iconographically in this way.

111 Ibid., 1: 125. English translation from Horn, Golden Age Revisited (see above, n. 2), 1: 293294. 
The situation was apparently so tense for Remonstrants that Lambert Jacobsz advised Camphuysen to take up a different trade for a time (though Camphuysen did not heed this advice right away). ${ }^{112}$ Even Camphuysen's own mother was hesitant to take him in for a night, since at that time "it was as dangerous to take a Remonstrant as a monster under one's roof."113

Within Camphuysen's biography, Houbraken also deigns to discuss and condemn the iconoclastic extremes taken by sixteenth-century Dutch Calvinists and carried forward in some stricter Reformed sentiments later on. Houbraken segues into the topic by clarifying that though Camphuysen translated a version of Johannes Geesteranus's late sixteenth-century Idololenchus, the former did not write this incendiary anti-art "Straf-Rym."114 Houbraken is affronted by the hard-line Calvinist iconoclastic argument against art and imagery on grounds of idolatry, which is the basis for Geesteranus's poem. To make his point, Houbraken first tactfully moves away from Dutch history and instead explores the example of Roman Emperor Julius and the folk of antiquity. He asks who is at fault for the idolatrous worship of statues of Jupiter, Mars, Mercury and others. Then, he jumps to the situation of "a certain statue carver" who makes a statue of Christ from palm wood, and upon getting sick is presented with this same statue by a priest, who is shocked and wonders why the sick man shows no reverence for the statue. To this the artist replies, "would I not recognize what I myself made from palm wood?"115 Houbraken emphasizes it is not the artist, but society's leaders, "motivated by shameful ambition," who are at fault for "[forcing] the subjects to bow before [the statues]."116 Houbraken asserts that it is not art itself that is problematic, though there is potential for misuse of art. Then he concludes tongue-in-check, noting that Geesteranus might have done as well to warn more about wine, which too is very often abused though not at fault in itself. He proposes the following couplet as a poem that exhibits much better understanding of the state of things:

These Statues made from paint, from wood, or stone,

Do these also make Gods? No: rather those who pour out prayers [to them]..$^{117}$

\footnotetext{
112 Houbraken, De groote schouburgh (see above, n. 1), 1: 126; Horn, Golden Age Revisited (see above, n. 2), 284 .

113 Houbraken, De groote schouburgh (see above, n. 1), 1: 126.

114 Horn, Golden Age Revisited (see above, n. 2), 1: 285. Also see Rabus, Het leven van Dirk Rafelsz. Kamphuizen (see above, n. 106), 1: 30 .

115 Houbraken, De groote schouburgh (see above, n. 1), 1: 127.

116 Ibid., $1: 127$.

117 Ibid., 1:127.
} 
Then he concludes his apology for art with this excerpt from Wetsteen der vernuften [Sharpening Stone of Ingenuity] (1644) by Jan de Brune ["de Jonge"] (1616-1649), an author who, like Houbraken, brought together topics of theology, philosophy, art, and antiquity in his writing. The lines are as follows:

The blame you give if you do something intoxicated

[is to the] Wine and [yet the wine] did not do it, but he who drank it. ${ }^{118}$

Houbraken takes the side of the artists and art in his discussion of the image debate, even though he has been part of faith traditions (Mennonite and Reformed) that both abstained from use of imagery, icons, and most forms of décor in the worship space. In doing so, he follows in the footsteps of Karel van Mander, who likewise had only had harsh words and names for the sixteenthcentury iconoclasts in his Schilder-Boeck of $1604 .{ }^{119}$

In his biographies, Houbraken positions himself against closed-minded, superstitious thinking and he cultivates sympathy for those persecuted on religious grounds. While focusing on art, and also on the problems of intolerance, he generally tries to avoid highlighting either Protestants or Catholics as the "persecutors." ${ }^{120} \mathrm{He}$ also does not suggest artists' religious affiliations are heretical. ${ }^{121}$ However, he does speak sceptically of religious happenings that he finds irrational. ${ }^{122} \mathrm{He}$ also occasionally points out instances when extremes of piety have been cause for slowed or halted artistic productivity. For instance, Houbraken highlights that he does not expect much more output from the skilled Rembrandt pupil Arendt de Gelder $\left(1645^{-1727}\right)$ since the artist has already for some time primarily occupied himself with "attending church and visiting friends." 123 On two occasions, he identifies what he calls "fanatical"

118 Ibid., 1:128.

119 Van Mander calls iconoclasts ontsinnighe ghemeen (senseless mobs), and he is disdainful of their woest overstandt (insane ignorance), snoode handen (evil hands), and onverstandighen yver (mindless fanaticism). See Charles Ford, "Iconoclasm, the Commodity, and the Art of Painting," in Iconoclasm: Contested Objects, Contested Terms, ed. Stacy Boldrick and Richard Clay (Abingdon, 2007), 75-92.

120 Horn, Golden Age Revisited (see above, n. 2), 1: 283-296.

121 The word "ketters" [heretics] actually only appears once in the book. See the account of Bartram de Fourchier: Houbraken is positive about Pope Urban viII's patronage program, but he is critical of some Spaniards who report on the Dutch travellers because they suspect the artists are "heretics." Houbraken, De groote schouburgh (see above, n. 1), 3: 339 .

122 Horn, Golden Age Revisited (see above, n. 2), 1: 283-296.

123 Houbraken, De groote schouburgh (see above, n. 1), 3: 208; Horn, Golden Age Revisited (see above, n. 2), 1: 288. De Gelder was also from Dordrecht and studied with Van Hoogstraten. It appears De Gelder and Houbraken were acquainted and even discussed matters pertain- 
practices of reclusive piety. After a long complimentary biography of polyglot and amateur artist Anna Maria van Schurman (1607-1678), he concludes by noting that, "supposedly wishing to serve the humble Jesus in simplicity," she turned to "Labadist fanaticism [Labadeesche dweepery]," which "took her away from Utrecht and her friends" to live in Altona "where a community of the like-minded had been established."124 He also discusses prolific printmaker Jan Luyken (1649-1712) —a Mennonite and Collegiant sympathiser turned popular mystic who was also the illustrator of the 1685 Martyrs Mirror. Houbraken explains that Luyken was an avid reader of the spiritual alchemist Jakob Böhme (1575-1624) and the French prophet Antoinette Bourignon (1616-1680), and he kept company with almost no one who did not adhere "to the same fanaticisms [dweeperyen]." ${ }^{125} \mathrm{He}$ describes the artist's reclusive behaviours and implies these reached the point of impinging on his family's needs. Given Houbraken's own heterodoxy and engagement with unconventional thinkers, his sometimes critical or joking tone suggests issues with piety taken to impractical extremes (especially if this curtailed artists' careers) rather than distaste for heterodoxy or religiousness per se, though conclusions on the particulars of this would require further exploration of Houbraken's theological writings. ${ }^{126}$ As Horn has discovered, Houbraken expresses his disagreement with the theology of Antoinette Bourignon in his Letters of Philalethes; ${ }^{127}$ so, this may have something to do with his critique of Luyken's interests. Reclusive landscape and nature painter Nicolaas de Vree is also described as one who "like Jan Luyken

ing to the representation of the crucifixion; on this, Horn, 1: 425-428; Hecht, "Browsing in Houbraken" (see above, n. 5), 263-274.

124 Houbraken, De groote schouburgh (see above, n. 1), 1: 315. The Labadists were followers of the Frenchman and former Jesuit, Jean de Labadie (1610-1674); they were characterized by their mystical asceticism, equality between the sexes, and commitment to living with goods held in common. On Schurman, see Joyce Irwin, "Anna Maria van Schurman: From Feminism to Pietism," Church History 46 (1977), 48-62; and Mirjam de Baar, et al., eds., Choosing the Better Part: Anna Maria van Schurman (1607-1678) (Dordrecht, 1996).

125 Houbraken, De groote schouburgh (see above, n. 1), 3: 254-255. Houbraken does not mention Luyken's initial Mennonite membership, nor his connections among the Collegiants.

126 Horn's views on Houbraken's position regarding organized religion vary, but he generally suggests Houbraken holds a "benign indifference to religious observance of any kind," dislike of organized religion, and "aversion to overt piety." See Horn, Golden Age Revisited (see above, n. 2), 1: 29 o and passim. Further study of Houbraken's theological writing would offer further clarity about the nuances on this topic.

127 On Bourignon, see Houbraken, Brieven van Philalethes (see above, n. 38), 4-5:27-38, especially 27; noticed by and cited in Horn, Golden Age Revisited (see above, n. 2), 1: 50, 62, and 2: 725, n. 2-224/2-225, and 731, n. 2-28o. For recent scholarship on Bourignon, see Mirjam de Baar, "Ik moet spreken": Het spiritueel leiderschap van Antoinette Bourignon (1616-1680) (Zutphen, 2004). 
held to the views of J. Bhoem [sic]."128 However, in this short biography he does not make reference to fanaticism.

As with the sixteenth-century cast of characters, including martyrs, dissenters, and religious reformers, Houbraken's biographies of seventeenth-century artists - taken together-offer a picture of the religious milieu of the era as seen through one observer's eyes. Houbraken occasionally explicitly identifies artists' church leadership roles, highlighting religious diversity. For example, he names Aart Jansz Druyvesteyn (1577-1627) and Albert Cuyp (1620-1691) respectively as elders of the Dutch Reformed church. ${ }^{129} \mathrm{He}$ also offers a glowing review of the flower paintings of Jesuit Daniel Seghers (1590-1661), and describes his experience visiting a chapel decorated with Seghers's work in a Catholic church in Brabant. ${ }^{130}$ Other stories shed light on religious experience via description of incidents (whether big or small) to do with religion in artists' daily lives. Even the biographies that are silent on religious matters-which constitute the majority - are informative. Silence on the subject suggests an artists' career or legacy that was not marked by significant local stories or written documentation of religious difference and difficulty — since, clearly, when records and sources did indicate religious turmoil in an artist's life, Houbraken was not shy about presenting these incidents in anecdotes. This possibility for success and collaboration among adherents of different denominations has indeed been recognized as an aspect of the Dutch seventeenth-century art marketplace that contributed to its success, and this characteristic too is reflected back to the readers within the pages of The Great Theatre. ${ }^{131}$

Conclusion

In his Great Theatre, Houbraken paints a picture of the diverse religious landscape experienced by early modern Dutch artists, as filtered through his interpretive lens. While Houbraken's biographies like those of Joris or Cuyck highlight and lament religious conflict, and biographies of Otto van Veen and Camphuysen astutely comment on the place of art in relation to religion and reli-

\footnotetext{
128 Houbraken, De groote schouburgh, 3: 318.

129 Ibid., 1: 61; 1: 249.

130 Ibid., 1: 140-141. The Jesuit and quasi-scientific alchemist Giuseppe Francesco Borri also makes an appearance. On him, Horn, Golden Age Revisited (see above, n. 2), 1: 287; Houbraken De groote schouburgh (see above, n. 1), 2: 286-287.

131 On Dutch artist-patron inter-denominational cooperation and pragmatism, see Volker Manuth, "Denomination and Iconography: The Choice of Subject Matter in the Biblical Painting of the Rembrandt Circle," Simiolus 22: 4 (1993-1994), 235-252.
} 
gious change, the many stories that are silent on religion point to instances when religious difference did not adversely affect artists' patronage opportunities or careers. The biographies in The Great Theatre enrich our understanding of Houbraken's own views regarding religious difference and religious change from the sixteenth through eighteenth centuries, and several of his biographies of contemporaries also offer insight on Houbraken's own biography as an unconventional Christian since he has included details about people from his direct context and network. From his Martyrs Mirror citation to his quotation of Van Mander via a publication of Goeree, Houbraken's writing in The Great Theatre offers a glimpse of the man as artist, reader, biographer, theorist, and heterodox Enlightenment thinker. 